DJS Vol. 37 (2016) 199-206

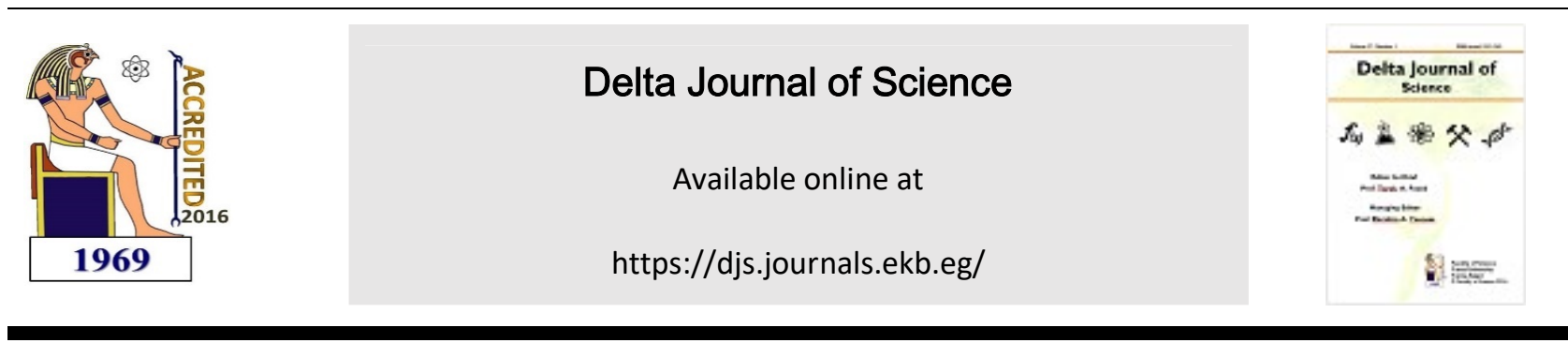

Research Article

\title{
Biodiesel Production from Scenedesmus obliquus Cultivated in Outdoor Conditions at Large Scale
}

Ahmed Darwish El-Gamal ${ }^{a}$, Mostafa El-Sheekh ${ }^{b}$, Alamo El-Din Bastawessic, Ahmad Abd El-Kader*b

${ }^{a}$ Botany and Microbiol. dept., faculty of science (Boys), Al-Azhar University, Cairo, Egypt

${ }^{\mathrm{b}}$ Phycology research unit, botany department, faculty of science, Tanta university, Tanta, Egypt

${ }^{*}$ Scientific assistant, Al-Azhar university, Tanta, Egypt

${ }^{c}$ Faculty of engineering, Tanta university, Tanta, Egypt

\begin{abstract}
Scenedesmus obliquus was discussed by phycologists as a promising microalga for biodiesel production based on its biomass and fatty acid productivity. In the present study, S. obliquus was pilot cultivated for large scale production in a semi continuous culture for three months using bubbled glass boxes photo- bioreactor. Cultivation of $S$. obliquus resulted in a maximum biomass productivity of $0.59 \mathrm{~g} \mathrm{~L}^{-1} \mathrm{~d}^{-1}$ and maximum esterified fatty acid productivity of $20.37 \mathrm{mg} \mathrm{l}^{-1} \mathrm{~d}^{-1}$ in (March, April and May), different flocculants for biomass harvest showed maximum flocculation efficiency of $82 \%$ using $250 \mathrm{mg} \mathrm{l}^{-1}$ of $\mathrm{NaOH}$ for $2 \mathrm{~h}$. Solar drying of the harvested biomass showed significant increase of esterified fatty acid content by $50 \%$ with respect to control. In addition, fatty acid profile and iodine number of $S$. obliquus oil meet biodiesel standard specifications which make the fatty acid of $S$. obliquus eligible for further research to be used as a feed stock for biodiesel production.
\end{abstract}




\section{Introduction}

Microalgae are the largest autotrophic microorganisms of plant life taxa in the world that can grow rapidly and live in harsh conditions due to their unicellular or simple multicellular structure. Microalgae are present in all existing earth ecosystems, not just aquatic but also terrestrial, representing a big variety of species living in a wide range of environmental conditions. It is estimated that more than 50,000 species exist, but only a limited number, of around 30,000, have been studied and analyzed (1).

The biomass produces three major biochemical components by denovo synthesis consisting of carbohydrates, proteins and lipids (natural oils)(2). Microalgae are known to synthesize and can rapidly accumulate substantially higher amounts of lipids than terrestrial plants due to their high growth rates (3), concomitantly by alteration of the lipid biosynthetic pathways for storage as neutral lipids. The lipid yields and growth rates vary significantly among different $\operatorname{species}(4,5)$. Micro algal lipids contain twice the energy stored per carbon atoms than carbohydrates, which translates directly into a twofold increase in fuel energy content thereby outcompeting terrestrial plants for biodiesel production (1).

Microalgae cultivation can be done in open-culture systems such as ponds or in highly controlled closed-culture systems called photo bioreactors $(6,7)$.

There are many methods for harvesting of microalgae like centrifugation, filtration and gravity sedimentation which may be preceded by a flocculation step(8). Choosing of the suitable method depends on algae species, growth medium, algae production, end product and production cost benefit (9). Various methods of flocculation can be used to aggregate the microalgae cells to increase the effective 'particle' size and hence ease sedimentation (10). Flocculation of algal biomass is preferred in large scale due to its low costs compared to other methods (11).

The present work was intended to throw some light on using of Scenedesmus obliquus as a feedstock for biodiesel production. This species was manipulated to stimulate fatty acid productivity and cultivated in large scale cultures. The quality of extracted oil as a source for biodiesel and recycling of byproducts were measured.

\section{Materials and methods}

\subsection{Cultivation of $S$. obliquus in large scale}

S. obliquus was cultivated in a bubbled glass boxes photo bioreactor. The system was built of $4 \mathrm{~mm}$ thick glass and had an internallength of $60 \mathrm{~cm}$, width of $30 \mathrm{~cm}$, a height of $35 \mathrm{~cm}$ and a nominal working volume of $40 \mathrm{~L}$. The dispersion system for the reactor consisted of an air pump located in the center of the system. The reactor was illuminated with (daylight-type). The duration of the light cycle was controlled by a timer. Airflow into the photo bioreactor was provided via filtered air through Teflontubing (fig.1)

S. obliquus was cultivated in 10 glass boxes each one was filled with $40 \mathrm{~L}$ of stock moh202 medium (see table 1) and 2L of 2 weeks-old inoculums previously grown in plastic bags in sun light. Temperature range between $16-30{ }^{\circ} \mathrm{C}$. The

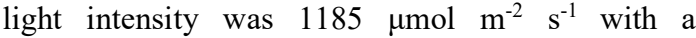
photoperiod 14:10 $\mathrm{h}$ light: dark. The $\mathrm{pH}$ was adjusted at $7 \pm 0.2$ by $\mathrm{pH}$ controller using air babbles.

\subsection{Biomass assay}

Algal growth was monitored using the optical density of the culture at $680 \mathrm{~nm}\left(\mathrm{OD}_{680}\right)$ using a Shimadzu UV $2401 \quad$ PC spectrophotometer and by determination of algal cellular dry weight (CDW). Biomass productivity was calculated according to (12). Biomass productivity (g $\left.\mathrm{CDWL}^{-1} \mathrm{~d}^{-1}\right)=$ $\left(C D W L-C D W_{E}\right) \cdot\left(t_{L}-t_{E}\right)^{-1}$ Where CDWE and CDWL representing the $\mathrm{CDW}\left(\mathrm{g} \mathrm{L}^{-1}\right)$ at days of

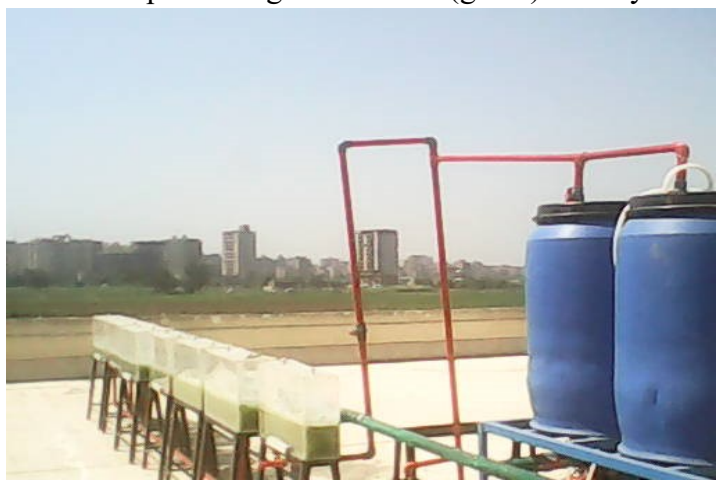

early exponential phase $\left(t_{E}\right)$ and late exponential phase $\left(t_{L}\right)$, respectively. 
Fig.1.Cultivation system of $S$. obliquus at large scale showing the glass boxes. Each one contains 40L of moh202 media in the sun light with a photoperiod 14:10 h light: dark and aerated using air pump.

Table1. Composition of Moh202 media pH 7.5 (12)

\begin{tabular}{ll}
\hline Elements & Nutrient Solution[g/L] \\
\hline $\mathrm{KNO}_{3}$ & 0.80 \\
$\mathrm{~K}_{2} \mathrm{HPO}_{4}$ & 0.15 \\
$\mathrm{KH}_{2} \mathrm{PO}_{4}$ & 0.20 \\
$\mathrm{CaCl}_{2}$ & 0.03 \\
$\mathrm{MgSO}_{4}$ & 0.10 \\
$\mathrm{NaCl}$ & 0.03 \\
$\mathrm{Hutner}$ 's trace elements* & $1.00 \mathrm{ml} \mathrm{l}^{-1}$ \\
$\mathrm{NaHCO}$ & 1.25 \\
Vitamin $\mathrm{B}_{1}$ & $0.12 \mathrm{mg} \mathrm{l}^{-1}$ \\
Vitamin $\mathrm{B}_{12}$ & $0.01 \mathrm{mg} \mathrm{l}^{-1}$ \\
\hline
\end{tabular}

Hunter's trace elements (1950) *

For 1-liter final mix, dissolve each compound in the volume of water indicated. The EDTA should be dissolved in boiling water, and the $\mathrm{FeSO}_{4}$ should be prepared last to avoid oxidation.

Table2. Hunter's trace elements (1950) *

\begin{tabular}{lll}
\hline compound & amount & water \\
\hline EDTA disodium salt & $50 \mathrm{~g}$ & $250 \mathrm{ml}$ \\
$\mathrm{ZnSO}_{4} .7 \mathrm{H}_{2} \mathrm{O}$ & $22 \mathrm{~g}$ & $100 \mathrm{ml}$ \\
$\mathrm{H}_{3} \mathrm{BO}_{3}$ & $11.4 \mathrm{~g}$ & $200 \mathrm{ml}$ \\
$\mathrm{MnCl}_{2} .4 \mathrm{H}_{2} \mathrm{O}$ & $5.06 \mathrm{~g}$ & $50 \mathrm{ml}$ \\
$\mathrm{CoCl}_{2} .6 \mathrm{H}_{2} \mathrm{O}$ & $1.61 \mathrm{~g}$ & $50 \mathrm{ml}$ \\
$\mathrm{CuSO}_{4} .5 \mathrm{H}_{2} \mathrm{O}$ & $1.57 \mathrm{~g}$ & $50 \mathrm{ml}$ \\
$\left(\mathrm{NH}_{4}\right)_{6} \mathrm{Mo}_{7} \mathrm{O}_{24 .} 4 \mathrm{H}_{2} \mathrm{O}$ & $1.10 \mathrm{~g}$ & $50 \mathrm{ml}$ \\
$\mathrm{FeSO}_{4} .7 \mathrm{H}_{2} \mathrm{O}$ & $4.99 \mathrm{~g}$ & $50 \mathrm{ml}$ \\
\hline
\end{tabular}

2.3. Biomass harvesting and drying

In this study, different flocculants were applied including $\mathrm{NaOH}$ and $\mathrm{Al}_{2}\left(\mathrm{SO}_{4}\right)_{3}$ to reduce the cost of harvest (12). Different concentrations $(0,50,150$ and $250 \mathrm{ppm})$ of $\mathrm{NaOH}$ and $\mathrm{Al}_{2}\left(\mathrm{SO}_{4}\right)_{3}$ were tested to harvest the cells with initial $\mathrm{OD}_{680}$ of $2.7\left(\mathrm{~A}_{1}\right)$ by flocculation. The flocculation efficiency was determined by measuring the $\mathrm{OD}_{680}$ at $2 \mathrm{~cm}$ from the bottom of the tube $\left(\mathrm{A}_{2}\right)$ according to Tao and Salihon (2011) Flocculation efficiency $=\left(\mathrm{A}_{1}\right.$ $\left.\mathrm{A}_{2}\right) / \mathrm{A}_{1} \times 100 \%$. After choosing the suitable flocculent, the culture was collected in $50 \mathrm{~L}$ container and mixed with suitable concentration of flocculent (270 ppm corresponding to $\mathrm{OD}_{680} 2.7$ ). The precipitated cells were collected after 2 hours of flocculation and dried(13).

The drying temperature before lipid extraction from algal biomass was found to affect the fatty acid content. It has been found that, the solar drying resulted in increase of fatty acid content by $50 \%$, with respect to control; in this test, the harvested cells were dried through -out the hours of the day.

\subsection{Extraction of lipid by Bligh and Dyer (1959):}

In detail, a 15-ml glass vial containing $20 \mathrm{~g}$ algal biomass, $100 \mathrm{ml}$ methanol, and $50 \mathrm{ml}$ chloroform were added and kept for $24 \mathrm{~h}$ at $25^{\circ} \mathrm{C}$. The mixture was agitated in a vortex for $2 \mathrm{~min}$. $50 \mathrm{ml}$ of chloroform was again added and the mixture was shaken vigorously for $1 \mathrm{~min}$. (fig.2). After, $50 \mathrm{ml}$ of distilled water was added and the mixture was mixed in a vortex again for $2 \mathrm{~min}$. fig.3. The layers were separated by separating funnel. The lower layer was collected into a previously weighed clean vial $\left(\mathrm{W}_{1}\right)$. Evaporation was carried on in a water bath and the residue was further dried at $104^{\circ} \mathrm{C}$ for $30 \mathrm{~min}$. The weight of the vial was again recorded $\left(\mathrm{W}_{2}\right)$. Lipid content was calculated by subtracting $\mathrm{W}_{1}$ from $\mathrm{W}_{2}$, and was expressed as \% D CW (14).

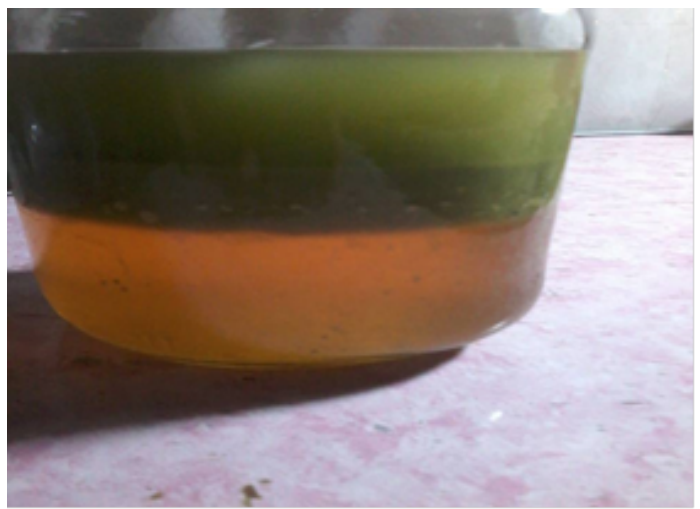

Fig.2. Extraction of lipid by Bligh and Dyer

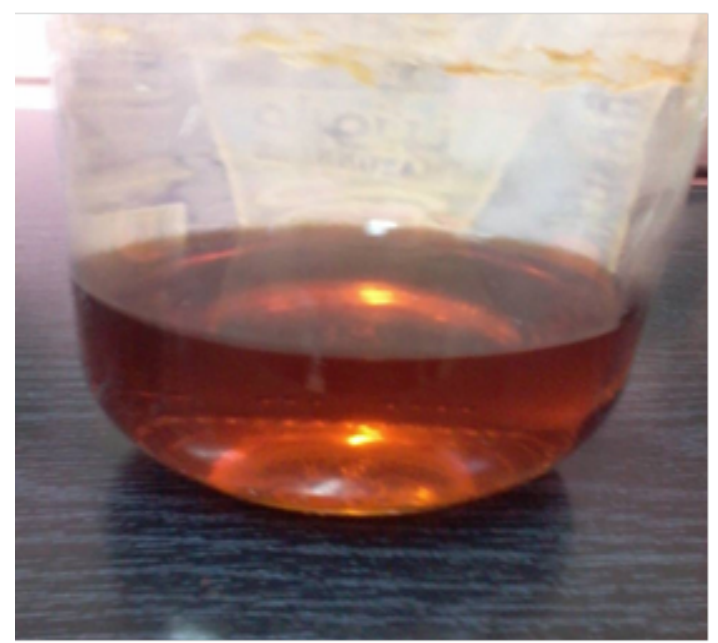

Fig.3. Lipid after washing and drying 


\subsection{Transesterification process}

In which, $0.5 \mathrm{~g}$ of $\mathrm{NaOH}$ and or $\mathrm{KOH}$ pettets were crushed with methanol. Then Stirring for 5-10 min until the $\mathrm{NaOH}$ and or $\mathrm{KOH}$ pettets were dissolved. Measure out $60 \mathrm{ml}$ of the algal oil. Add all the contents to the reaction flask. Heat the flask contents to $50 \mathrm{c}^{\circ}$ for $20 \mathrm{~min}$. with continuous stirring. While still warm, pour the mixture into a separating funnel and allow cooling until the mixture separates into two layers. The upper layer is biodiesel while the lower is glycerol. Don't let it stand for too long as the lower layer may solidify(15).

\subsection{Biodiesel quality}

Fatty acid composition was estimated by GC analysis and degree of unsaturation by determination iodine. The obtained values could be used as indicators for the quality of $S$. obliquus oil as a feedstock for biodiesel. The iodine value was determined according to the modified method of (16). $0.2 \mathrm{~g}$ of the oil was introduced in a dry glass stoppered Erlenmeyer flask. $25 \mathrm{ml}$ of the reagent A were added. A previously moistened stopper with KI solution was inserted for $1 \mathrm{~min}$, and then $10 \mathrm{ml}$ of $20 \%$ KI solution were added. The stopper and the neck of the flask were washed with water and the contents were diluted to $200 \mathrm{ml}$. The librated iodine was titrated with $0.1 \mathrm{~N}$ sodium thiosulphate solution using starch as indicator. A blank was carried out and the iodine value was calculated according to the following equation: $\mathrm{IV}=(\mathrm{B}-\mathrm{E}) * 1.27 / \mathrm{W}$, where: $\mathrm{IV}=$ iodine value $\mathrm{B}=$ weight of $0.1 \mathrm{~N}$ sodium thiosulphate of the blank $(\mathrm{g}) \mathrm{E}=$ weight of $0.1 \mathrm{~N}$ sodium thiosulphate of the sample $(\mathrm{g}) \mathrm{W}=$ weight of the oil (g) Reagent A: $45 \mathrm{ml}$ of dioxin and $6 \mathrm{ml}$ of bromine solution were added to $500 \mathrm{ml}$ of chloroform and mixed thoroughly. The volume was completed to 1 liter with chloroform then stored in a dark bottle.

\section{Results}

In order to keep costs down in large scale cultivation of microalgae, it is important to develop massive cultivation systems characterized by low cost, high biomass production and ease of handling. The growth pattern of $S$. obliquus cultivated in experimental photobioreactor for 2 weeks at different time periods of year. As a general trend, the increase in light intensity accelerated the growth and EFA content. Biomass productivity increased from $0.24 \mathrm{~g} \mathrm{~L}^{-1} \mathrm{~d}^{-1}$ in (October, November and December) to $0.59 \mathrm{~g} \mathrm{~L}^{-1} \mathrm{~d}^{-1}$ in (March, April and May) (fig.4). Also, EFA productivity of $S$. obliquus increased from $10.5 \mathrm{mg}$
$\mathrm{L}^{-1} \mathrm{~d}^{-1}$ at (October, November and December) to $20.37 \mathrm{mg} \mathrm{L}^{-1} \mathrm{~d}^{-1}$ at (March, April and May) (fig.5).

It has been found that, the solar drying resulted in increase of fatty acid content by $50 \%$, with respect to control (fig.6). In this test, the harvested cells were dried throughout the hours of the day.

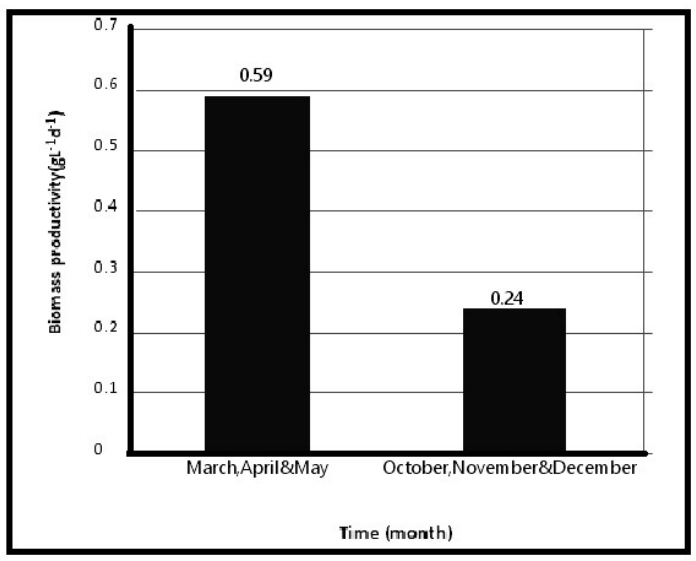

Fig.4. Biomass productivity of S.obliquus cultivated at different time periods of year.

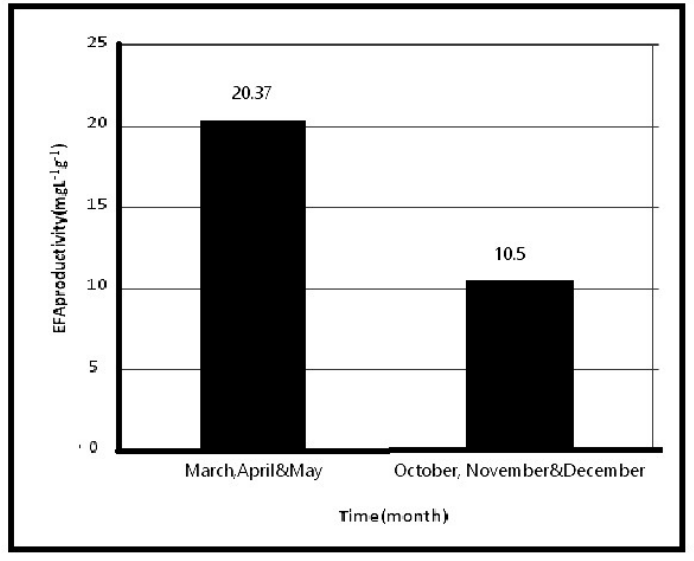

Fig.5. EFA productivity of S.obliquus cultivated at different time periods of year.

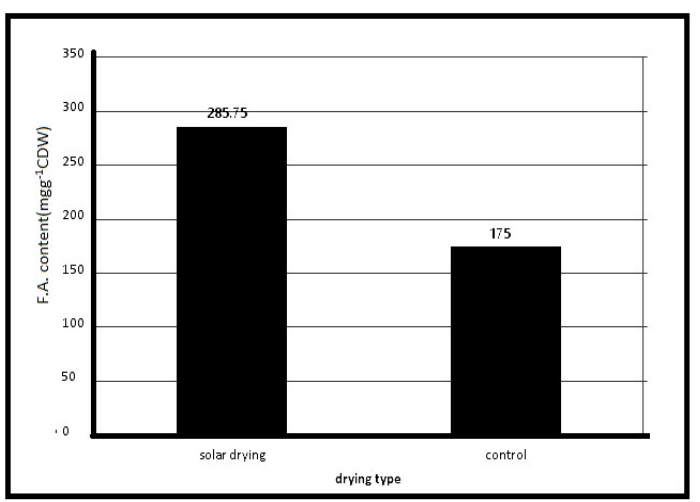


Fig.6. The effect of solar drying on fatty acid content of S. obliquus. Control means the fresh algal cells without drying, while solar drying was conducted using the sun throughout the hours of the day until constant weight.

As a general trend, the flocculation efficiency increased by increasing the flocculant concentration. The maximum efficiency for $\mathrm{Al}_{2}\left(\mathrm{SO}_{4}\right)_{3}$ was $75 \%$ using $270 \mathrm{ppm}$ after $2 \mathrm{~h}$ (fig.7), while the maximum flocculation efficiency for $\mathrm{NaOH}$ was $82 \%$ using $270 \mathrm{ppm}$ for $2 \mathrm{~h}$ (fig.8). Therefore, the harvest took place using $270 \mathrm{ppm}$ of $\mathrm{NaOH}$ corresponding to $\mathrm{OD}_{680} 2.7$ for $2 \mathrm{~h}$.

Coagulation of cells resulting in precipitation or floating to the surface may be induced by the addition of multivalent metal salts such as aluminium sulphate and ferric chloride. Recovery of the microalgal biomass is then accomplished by siphoning off the supernatant or skimming cells off the surface respectively. These multivalent metal salts e.g. aluminium sulphate are effective coagulants for Scenedesmus(17)

The acceptability of biodiesel from microalgae as a substitute of fossil diesel fuel is strongly dependent on compliance with existing standards. The benchmark standard currently is the European Union (EN 590:1999) (18). Table1 show the fuel properties of biodiesel from micro algal oil such as viscosity, heating value, density, viscosity, flash point and solidifying point.

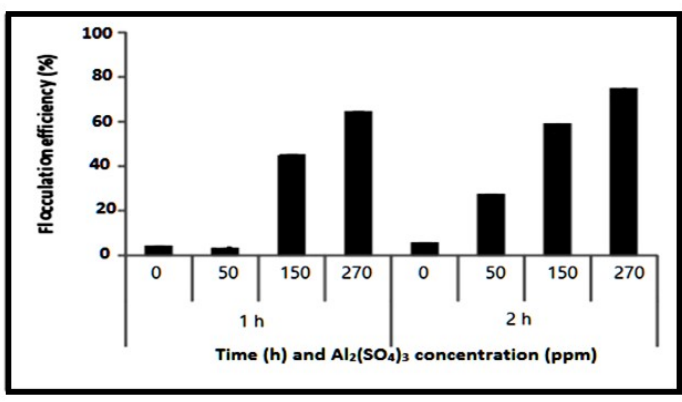

Fig.7.Flocculation of algal culture of Scenedesmus obliquus using different concentrations of $\mathrm{Al}_{2}\left(\mathrm{SO}_{4}\right)_{3}$ after 1 and 2 hours after mixing.

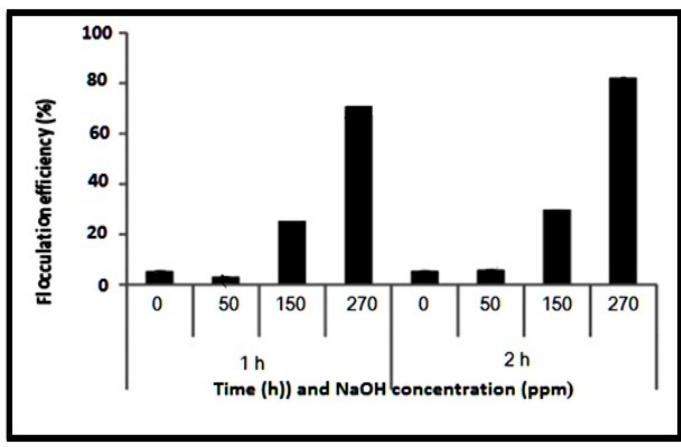

Fig.8.Flocculation of algal culture of Scenedesmus obliquus using different concentrations of $\mathrm{NaOH}$ after 1 and 2 hours from mixing

Table3. Comparison of properties of biodiesel from micro algal oil and diesel fuel

\begin{tabular}{|c|c|c|}
\hline Properties & $\begin{array}{l}\text { Biodiesel from } \\
\text { micro algal oil }\end{array}$ & $\begin{array}{l}\text { Diesel fuel } \\
\text { (EN } \\
590: 1999)\end{array}$ \\
\hline Density $(\mathrm{kg} / \mathrm{l})$ & 0.859 & 0.838 \\
\hline $\begin{array}{l}\text { Viscosity }\left(\mathrm{mm}^{2} /\right. \\
\mathrm{s}, \mathrm{cSt} \text { at } 40{ }^{\circ} \mathrm{C}\end{array}$ & 4.9 & $2-4.5$ \\
\hline Flash point $\left({ }^{\circ} \mathrm{C}\right)$ & 111 & $>55$ \\
\hline $\begin{array}{l}\text { Acid value (mg } \\
\mathrm{KOH} / \mathrm{g} \text { ) }\end{array}$ & 0.371 & $\max 0.5$ \\
\hline $\begin{array}{l}\text { Heating value } \\
(\mathrm{MJ} / \mathrm{kg})\end{array}$ & 39 & $40-45$ \\
\hline $\mathrm{H} / \mathrm{C}$ ratio & 1.81 & 1.81 \\
\hline $\begin{array}{l}\text { Solidifying } \\
\text { point }\left({ }^{\circ} \mathrm{C}\right)\end{array}$ & -12 & -50 to 10 \\
\hline
\end{tabular}

From fatty acid profile of $S$. obliquus revealed that, Lipids of $S$. obliquus were composed of $51 \%$ saturated and mono unsaturated fatty acids in the stationary phase. The predominant fatty acid at this growth phase was palmitic acid (16:0). The iodine value of $S$. obliquus was $70 \mathrm{~g}$ iodine/ $100 \mathrm{~g}$ oil. These results make the fatty acid composition of $S$. obliquus meet standard specifications of EN 590:1999(18).

4-conclusion

Microalgae have emerged as one the most promising feedstocks for biodiesel production(19). They have several key traits that make them a desirable energy source. They can be grown away from farmlands and forests and their yields of oil are higher than those from traditional oilseeds. In addition, they can provide several different types of high value derivatives such as nutritional supplements, antioxidants, cosmetics, natural dyes, and polyunsaturated fatty acids and renewable biofuels.

As a general trend, the increase in light intensity accelerated the growth and EFA content of $S$. obliquus(20-23). It has been founded that, the sun light intensity increase biomass productivity from $0.24 \mathrm{~g} \mathrm{~L}^{-1} \mathrm{~d}^{-1}$ at (October, November and December) to $0.59 \mathrm{~g} \mathrm{~L}^{-1} \mathrm{~d}^{-1}$ at (March, April and May). Also, EFA productivity of $S$. obliquus increased from 10.5 $\mathrm{mg} \mathrm{L}^{-1} \mathrm{~d}^{-1}$ at (October, November and December) to $20.37 \mathrm{mg} \mathrm{L}^{-1} \mathrm{~d}^{-1}$ at (March, April and May). 
Harvest of $S$. obliquus cells has been done by chemical flocculation. In this study, different flocculants were tested and $\mathrm{NaOH}$ was selected as the best one.

The iodine value of $S$. obliquus was $70 \mathrm{~g}$ iodine/ $100 \mathrm{~g}$ oil. These results make the fatty acid composition of $S$. obliquus meet standard specifications of EN 590:1999(18). Measurements of other parameters including density, viscosity, flash point, acid value heating value, $\mathrm{H} / \mathrm{C}$ ratio and solidifying are important to detect the suitability of S. obliquus oil for biodiesel.

Acknowledgement:

The authors gratefully acknowledge financial support from the office of the Tanta University Research Fund (Research Grant: cod-Tu;03-15-02). References

1. Mata TM, Martins AA, Caetano NS. Microalgae for biodiesel production and other applications: A review. Renewable and Sustainable Energy Reviews. 2010;14(1):217-32.

2. Sinha SK, Gupta A, Bharalee R. Production of biodiesel from freshwater microalgae and evaluation of fuel properties based on fatty acid methyl ester profile. Biofuels. 2016:1-17.

3. Metting Jr F. Biodiversity and application of microalgae. Journal of industrial microbiology. 1996;17(5-6):477-89.

4. Chisti Y. Biodiesel from microalgae. Biotechnology advances. 2007;25(3):294-306.

5. Hu Q, Sommerfeld M, Jarvis E, Ghirardi M, Posewitz M, Seibert M, et al. Microalgal triacylglycerols as feedstocks for biofuel production: perspectives and advances. The Plant Journal. 2008;54(4):621-39.

6. Chen Y, Wang J, Zhang W, Chen L, Gao L, Liu T. Forced light/dark circulation operation of open pond for microalgae cultivation. Biomass and Bioenergy. 2013;56:464-70.

$7 . \quad$ Roselet F, Maica P, Martins T, Abreu PC. Comparison of open-air and semi-enclosed cultivation system for massive microalgae production in sub-tropical and temperate latitudes. Biomass and Bioenergy. 2013;59:418-24.

8. Grima EM, Belarbi E-H, Fernández FA, Medina AR, Chisti Y. Recovery of microalgal biomass and metabolites: process options and economics. Biotechnology advances. 2003;20(7):491-515.

9. Shelef G, Sukenik A, Green M. Microalgae harvesting and processing: a literature review. Technion Research and Development Foundation Ltd., Haifa (Israel), 1984.

10. Elmaleh S, Coma J, Grasmick A, Bourgade L. Magnesium induced algal flocculation in a fluidized bed. Water Science and Technology. 1991;23(7-9):1695-702.
11. Bilanovic D, Shelef G, Sukenik A. Flocculation of microalgae with cationic polymerseffects of medium salinity. Biomass. 1988;17(1):6576.

12. El-Sheekh M, Abomohra AE-F, Hanelt D. Optimization of biomass and fatty acid productivity of Scenedesmus obliquus as a promising microalga for biodiesel production. World Journal of Microbiology and Biotechnology. 2013;29(5):91522.

13. Tao DG, Salihon J, editors. The Optimisation of levels of the variables $\mathrm{pH}$ and Concentration of Ferric chloride for Harvesting marine microalgae by flocculation. Proceedings of the International Conference on Food Engineering and Biotechnology (IPCBEE); 2011: IACSIT Press.

14. Bligh EG, Dyer WJ. A rapid method of total lipid extraction and purification. Canadian journal of biochemistry and physiology. 1959;37(8):911-7.

15. Macías-Sánchez $\mathrm{M}$, Robles-Medina A, Hita-Peña E, Jiménez-Callejón M, Estéban-Cerdán L, González-Moreno P, et al. Biodiesel production from wet microalgal biomass by direct transesterification. Fuel. 2015;150:14-20.

16. Said SI, Longacher JW, Davis RK, Banerjee CM, Davis WM, Wooddell WJ. Pulmonary gas exchange during induction of pulmonary edema in anesthetized dogs. Journal of applied physiology. 1964;19(3):403-7.

17. Rawat I, Kumar RR, Mutanda T, Bux F. Biodiesel from microalgae: A critical evaluation from laboratory to large scale production. Applied Energy. 2013;103:444-67.

18. Miao X, Wu Q. Biodiesel production from heterotrophic microalgal oil. Bioresource technology. 2006;97(6):841-6.

19. Han S-F, Jin W-B, Tu R-J, Wu W-M. Biofuel production from microalgae as feedstock: current status and potential. Critical reviews in biotechnology. 2015;35(2):255-68.

20. Brown MR, Dunstan GA, Norwood S, Miller KA. Effects of harvest stage and light on the biochemical composition of the diatom thalassiosira pseudonana1. Journal of Phycology. 1996;32(1):6473.

21. Khotimchenko SV, Yakovleva IM. Lipid composition of the red alga Tichocarpus crinitus exposed to different levels of photon irradiance. Phytochemistry. 2005;66(1):73-9.

22. Napolitano GE. THE RELATIONSHIP OF LIPIDS WITH LIGHT AND CHLOROPHYLL MEASUREMENTS IN FRESHWATER ALGAE AND PERIPHYTON1. Journal of Phycology. 1994;30(6):943-50.

23. Spoehr H, Milner HW. The chemical composition of Chlorella; effect of environmental conditions. Plant Physiology. 1949;24(1) 


\section{الملخص}

اظهرت الدراسات السابقة ان السيندمس اوبليكس واحده من المواد الاولية الواعدة في مجال انتاج وقود الديزل

الحيوي على اساس المحتوى الدهني ومعدلات النمو العالية .وفي هذه الدراسة تم اختيار السبندزمس اوبليكس للزر اعة لمدة ثلاثة اثهر على نطاق واسع باستخدام صناديق زجاجية شفافة كمفاعل ضوئي تجريبي. اظهرت النتائج ان زراعة السيندزمس اوبلبكس في اشهر(مارس ابريل مايو) يعطي انتاجية اعلى في معدلات النهو وانتاجية الاحماض الدهنية عنها في اشهر (اكتوبر نوفمبر ديسمبر) بمعدل يصل الى 60\% . في هذه الدر اسة استخدمت طريقة الترسيب باستخدام مو اد كيميائية فى حصاد خلايا

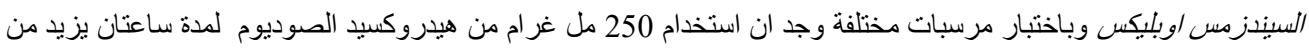
معدل الترسيب بنسبة تصل الى 82\% عنها في المعدل الطبيعي ـ وباستخدام التجفيف الثمسي وجد ان هناك زياد ملحوظة في محتوى الاحماض الدهنية تصل الى 50\%عن تلك التي تجف باستخدام الافران الكهربية .و اعتمادا على أنو اع الاحماض الدهنية و الرقم اليودى للمو اد الدهنية فى السيندزمس اوبليكس يتضح أن الزيت المستخرج منها مطابق للمعايير الاوروبية لاستخدامه 